\title{
Mengukur Tingkat Kesehatan Koperasi Simpan Pinjam Berdasarkan Peraturan Nomor: 06/PER/DEP.6/IV/2016 (Studi Kasus Pada Koperasi Abdi Sesama - Palembang)
}

\author{
Andreas Rudiwantoro \\ Universitas Bina Sarana Informatika \\ PSDKU KARAWANG \\ e-mail : andreas.aed@bsi.ac.id
}

Rudiwantoro, A. (2019). Mengukur Tingkat Kesehatan Koperasi Simpan Pinjam Berdasarkan Peraturan No: 06/PER/DEP.6/IV/2016 (Studi Kasus Pada Koperasi Abdi Sesama - Palembang). Moneter, 6(1), 45-52.

\begin{abstract}
The aim of this research is to discover the health level of Saving Loan Cooperative Abdi Sesama in 2017. The research refer to cooperation financial statement 2017 only. The data analysis tehniques base on the Standard of the Minister of Coopertive and Small, Medium Enterprises Republic of Indonesia number: 06/Per/Dep.6/IV/2016. The Data collection techniques used are documentation and interview. Techniques documentation in the form of cooperation financial statement 2017 and interviews are conducted to measure healhty level for management aspect. Primary data and secondary data used in this research. Final results of this research show the Saving Loan Cooperative Abdi Sesama has healthy predicate, with grand total score 81,65 .
\end{abstract}

Keywords: Health level, Saving and Loan Cooperative, Cooperation Financial Statement

\section{PENDAHULUAN}

Koperasi simpan pinjam adalah salah satu bentuk badan usaha yang diatur oleh pemerintah melalui (Undang-Undang Republik Indonesia Nomor 25 Tahun 1992, 1992), memiliki tujuan memberikan manfaat yang sebesar-besarnya bagi seluruh anggotanya. Pemerintah sangat menyadari bahwa pertumbuhan ekonomi nasional tidak dapat disandarkan hanya kepada BUMD, BUMN ataupun perusahan perusahan swasta skala kecil maupun skala besar. Kehadiran koperasi juga telah memberi dampak positif bagi pertumbuhan ekonomi nasional.

Koperasi simpan pinjam dapat diartikan sebagai badan usaha yang dimiliki sekumpulan orang dalam ikatan pemersatu yang sepakat menabung sehingga terciptanya modal untuk pinjaman antar anggota.

Pada koperasi simpan pinjam, ada tiga prinsip yang melekat, yaitu adanya swadana, senasib sepenanggungan dan yang terakhir adalah kerja sama dan saling percaya. Koperasi simpan pinjam merupakan sebuah lembaga keuangan non bank yang dikelola dan dijalankan untuk memberikan bantuan pinjaman modal kerja kepada para anggota dengan tingkat suku bunga kredit rendah. Memberikan solusi keuangan atau permodalan kepada anggota koperasi. Koperasi hendaknya terus meningkatkan kualitas untuk menumbuhkan kepercayaan para anggota, masyarakat dan pihak ketiga (pemerintah dan bank).
Kualitas koperasi tidak hanya diukur dari besarnya modal, besarnya jumlah anggota dan aspek laporan keuangan.

Kualitas koperasi dapat di ukur dari tingkat kesehatan koperasi itu sendiri. Penilaian kesehatan koperasi simpan pinjam merupakan suatu hal penting di Indonesia. Menurut (Deputi Bidang Pengawasan Kementerian Koperasi Dan Usaha Kecil Dan Menengah Republik Indonesia, 2016) disebutkan bahwa sasaran penilaian kesehatan usaha Koperasi Simpan Pinjam (KSP) dan Usaha Simpan Pinjam (USP) koperasi adalah sebagai berikut:

1. Terwujudnya pengelolaan KSP dan USP koperasi yang sehat dan sesuai ketentuan peraturan perundang-undangan.

2. Terwujudnya pelayanan prima kepada pengguna jasa koperasi.

3. Meningkatnya citra dan kredibiitas kegiatan usaha simpan pinjam oleh koperasi sebagai lembaga keuangan yang mampu mengelola kegiatan usaha simpan pinjam sesuai dengan peraturan perundang - undangan.

4. Terjaminnya aset kegiatan usaha simpan pinjam oleh koperasi sesuai dengan peraturan perundang - undangan.

5. Meningkatnya transparansi dan akuntabilitas pengelolaan kegiatan usaha simpan pinjam oleh koperasi.

6. Meningkatnya manfaat ekonomi anggota dalam kegiatan usaha simpan pinjam oleh koperasi. 
Lebih lanjut diuraikan ada 22 indikator untuk menilai kesehatan KSP dan USP Koperasi, seperti yang tertuang dalam Peraturan (Deputi Bidang Pengawasan Kementerian Koperasi Dan Usaha Kecil Dan Menengah Republik Indonesia, 2016). 22 indikator tersebut terbagi dalam 7 aspek, yaitu:

1. Aspek Permodalan; terdiri dari (a) Rasio modal sendiri terhadap total asset, (b) Rasio modal sendiri terhadap pinjaman diberikan yang berisiko, (c) Rasio kecukupan modal sendiri.

2. Aspek Kualitas Aktiva Produktif; terdiri dari (a) Rasio volume pinjaman pada anggota terhadap volume pinjaman diberikan, (b) Rasio risiko pinjaman bermasalah terhadap pinjaman yang diberikan, (c) Rasio cadangan risiko terhadap pinjaman bermasalah, (d) Rasio pinjaman yang berisiko terhadap pinjaman yang diberikan.

3. Aspek Manajemen; terdiri dari (a) Manajemen umum, (b) Kelembagaan, (c) Manajemen permodalan, (d) Manajemen aktiva, (e) Manajemen likuiditas.

4. Aspek Efisiensi; terdiri dari (a) Rasio beban operasi terhadap partisipasi bruto, (b) Rasio beban usaha terhadap SHU kotor, (c) Rasio efisiensi pelayanan.

5. Aspek Likuiditas; terdiri dari (a) Rasio kas, (b) Rasio pinjaman yang diberikan terhadap dana yang diterima.

6. Aspek Kemandirian dan pertumbuhan; terdiri dari (a) Rentabilitas asset, (b) Rentabilitas modal sendiri, (c) Kemandirian operasional pelayanan.

7. Aspek Jatidiri; terdiri dari (a) Rasio partisipasi bruto, (b) Rasio Promosi ekonomi anggota (PEA)

Mengacu pada(Deputi Bidang Pengawasan Kementerian Koperasi Dan Usaha Kecil Dan Menengah Republik Indonesia, 2016), hasil penilaian kesehatan KSP dan USP Koperasi diklasifikasi dalam empat kategori, yaitu:

1. Sehat, jika hasil penilaian diperoleh total skor $80,00 \leq X \leq 100$

2. Cukup sehat, jika hasil penilaian diperoleh total skor $66,00 \leq \mathrm{X}<80,00$

3. Dalam pengawasan, jika hasil penilaian diperoleh total skor $51,00 \leq \mathrm{X}<66,00$

4. Dalam pengawasan khusus, jika hasil penilaian diperoleh total skor $0 \leq \mathrm{X}<51,00$

Dalam (Goenawan \& Natalia, 2016), disebutkan bahwa penilaian terhadap tingkat kesehatan koperasi untuk mengetahui seberapa sehatnya koperasi dalam melaksanakan usahanya dan koperasi dapat mengevaluasi kegiatan yang selama ini telah dilakukan guna keberlangsungan usahanya dan pihak-pihak yang terkait dengan koperasi akan merasa lebih nyaman dan aman apabila berurusan dengan koperasi, baik itu masalah investasi, pinjaman, kewajiban terhadap pemerintah (pajak) dan lain-lainnya.

Koperasi simpan Pinjam Abdi Sesama, beralamat di jalan kolonel Atmo No. 869 Palembang Sumatera Selatan. Didirikan dengan payung hukum nomor BH: 001931a/BH/Tgl. 23 Juli 1997, dan sampai dengan tahun 2017 sudah memiliki anggota sebanyak 832 orang. Perkembangan jumlah anggota dari tahun 2015 sampai tahun 2017 dalam dilihat dalam tabel 1 dibawah ini

Tabel 1. Keanggotaan Koperasi

\begin{tabular}{ll}
\hline Tahun & Jumlah \\
\hline 2015 & 823 orang \\
\hline 2016 & 814 orang \\
\hline 2017 & 832 orang \\
\hline
\end{tabular}

Modal sendiri dari koperasi Abdi Sesama dihimpun dari simpanan pokok, simpanan wajib dan dana cadangan. Pertumbuhan modal sendiri dari tahun 2015 sampai tahun 2017 dapat dilihat pada tabel 2 dibawah ini

Tabel 2. Modal Sendiri/Simpanan Anggota

\begin{tabular}{ll}
\hline Tahun & Jumlah $(\mathrm{Rp})$ \\
\hline 2015 & 4.269 .319 .984 \\
\hline 2016 & 4.577 .032 .662 \\
\hline 2017 & 4.866 .585 .822 \\
\hline
\end{tabular}

Sumber: Data Primer

Sementara untuk pergerakan realisasi pinjaman kepada anggota, total asset dan sisa hasil usaha (SHU) dari tahun 2015 sampai tahun 2017 dapat dilihat pada tabel 3 dibawah ini.

Tabel 3.

Realisasi Pinjaman, Total Asset \& Total SHU

(Dalam Ribuan Rupiah)

\begin{tabular}{lrrr} 
Tahun & Realisasi Pinj & Total Asset & SHU \\
\hline 2015 & 3.115 .800 & 9.623 .495 & 3.444 \\
\hline 2016 & 2.951 .400 & 10.054 .494 & 158.273 \\
\hline 2017 & 3.483 .350 & 11.607 .182 & 166.873 \\
\hline
\end{tabular}

Sumber: Data Primer

Melihat usia koperasi Abdi Sesama yang tidak muda lagi maka sudah seharusnya koperasi mampu bersaing ataupun berkompetisi dengan koperasi lainnya yang ada di kota Palembang. Untuk dapat berkompetisi tidak hanya ditentukan oleh besarnya modal kerja yang dimiliki atau besarnya jumlah anggota dan ataupun oleh faktor laporan keuangan, tetapi yang terpenting adalah tingkat kesehatan 
koperasi yang prima. Melakukan pengukuran terhadap tingkat kesehatan koperasi merupakan suatu hal penting dan mutlak agar terwujud pengelolaan KSP yang sesuai dengan peraturan perundang-undangan.

Atas dasar pemikiran tersebut diatas maka penulis tertarik untuk mengupasnya dalam bentuk jurnal dengan judul Mengukur Tingkat Kesehatan Koperasi Simpan Pinjam Berdasarkan Peraturan Nomor: 06/PER/ DEP.6/IV/2016.

Adapun yang menjadi tujuan dari penelitian ini adalah untuk mengetahui tingkat kesehatan koperasi Abdi Sesama, apakah masuk dalam predikat sehat, cukup sehat, dalam pengawasan dan atau dalam pengawasan khusus.

\section{Pengertian Koperasi.}

Pengertian koperasi sendiri berasal dari kata cooperatio yang berarti usaha bersama. Secara umum koperasi dipahami sebagai perkumpulan orang yang secara sukarela mempersatukan diri untuk memperjuangkan peningkatan kesehateraan ekonomi mereka, melalui pembentukan sebuah perusahaan yang dikelola secara demokratis (Baswir, 2000).

Di sisi lain, pengertian koperasi secara umum adalah suatu perkumpulan yang beranggotakan orang-orang atau badan hukum, yang memberikan kebebasan kepada anggota untuk masuk dan keluar, dengan bekerja sama secara kekelurgaan menjalankan usaha untuk mempertinggi kesejahteraan para anggotanya (Sumarsono, 2003).

Dalam (Undang-Undang Republik Indonesia Nomor 25 Tahun 1992, 1992) ditegas-kan bahwa Koperasi Indonesia adalah badan usaha yang beranggotakan orang seorang atau badan hukum koperasi dengan melandaskan kegiatannya berdasarkan prinsip koperasi sekaligus sebagai gerakan ekonomi rakyat yang berdasarkan atas azas kekeluargaan..

Prinsip-prinsip koperasi berdasarkan (UndangUndang Republik Indonesia Nomor 2 Tahun 1992, 1992) adalah sebagai berikut; (a) Keanggotaan bersifat sukarela dan terbuka, (b) Pengelolaan dilakukan secara demokrasi, (c) Pembagian SHU dilakukan secara adil sesuai dengan jasa usaha masing masing anggota, (d) Pembagian balas jasa yang terbatas pada modal, (e) Kemandirian, (f) Pendidikan perkoperasian, (g) Kerjasama antar koperasi.

(Subandi, 2009), mengelompokan jenis koperasi berdasarkan bidang usahanya sebagai berikut:

a. Koperasi Konsumsi. Koperasi yang berusaha dalam bidang penyediaan barang-barang konsumsi yang dibutuhkan oleh para anggotanya. Jenis konsumsi yang dilayani oleh suatu koperasi sangat tergantung pada ragam anggota dan daerah kerja tempat koperasi didirikan.

b. Koperasi Produksi. Koperasi yang kegiatan usahanya memproses bahan baku menjadi barang jadi atau setengah jadi . Tujuannya adalah untuk menyatukan kemampuan dan modal para anggotanya guna meningkatkan barang-barang tertentu melalui proses yang meratakan pengelolaan dan memiliki sendiri.

c. Koperasi Pemasaran. Koperasi yang dibentuk terutama untuk membantu para anggotanya dalam memasarkan barang-barang yang dihasilkan. Tujuannya adalah untuk menyederhanakan mata rantai niaga, dan mengurangi sekecil mungkin keterlibatan perantara dalam memasarkan produk-produk yang dihasilkan.

d. Koperasi Kredit atau Koperasi Simpan Pinjam. Koperasi yang bergerak dalam pemupukan simpanan dari para anggotanya untuk dipinjamkan kembali kepada para anggotanya yang membutuhkan bantuan modal untuk usahanya. Selain itu koperasi simpan pinjam juga bertujuan untuk mendidik anggotanya untuk bersifat hemat dan gemar menabung serta menghindarkan anggotanya dari jeratan para rentenir.

\section{Laporan Keuangan Koperasi}

(Kasmir, 2010)Dalam pengertian yang sederhana, laporan keuangan adalah laporan yang menunjukkan kondisi keuangan perusahaan pada saat ini atau dalam suatu periode tertentu. Laporan keuangan merupakan sumber penting dalam sebuah badan usaha ataupun koperasi karena sebagai media informasi yang mencatat ringkasan dari transaksitransaksi keuangan selama tahun buku yang bersangkutan. Dimana melalui laporan keuangan, para anggota koperasi dapat mengetahui kondisi kinerja pengurus koperasi pada periode tertentu.

(Jumingan, 2011) Laporan keuangan merupakan suatu proses akuntansi yang menghasilkan wujud atau cerminan kondisi keuangan dan hasil operasi perusahaan. Suatu hasil dari laporan keuangan sangatlah penting untuk dipelajari atupun dianalisis, untuk mengetahui posisi keuangan perusahaan tersebut. (Harapan, 2009) Analisis laporan keuangan berarti menguraikan akun-akun laporan keuangan menjadi unit informasi dan melihat hubungannya yang bersifat signifikan dengan tujuan untuk mengetahui kondisi keuangan lebih dalam untuk menghasilkan keputusan yang tepat.

(Margaretha, 2011)Mendefinisikan laporan keuangan sebagai laporan yang memberikan gambaran akuntansi atas operasi serta posisi keuangan perusahaan.

(Fahmi, 2011) Laporan keuangan merupakan suatu informasi yang menggambarkan kondisi perusahaan, 
dimana selanjutnya itu akan menjadi suatu informasi yang menggambarkan tentang kinerja suatu perusahaan.

Berdasarkan pengertian-pengertian laporan keuangan tersebut diatas, maka yang dimaksud dengan laporan keuangan koperasi adalah hasil tindakan pembuatan ringkasan data keuangan koperasi oleh pengurus yang memberikan gambaran akuntansi atas operasi serta posisi keuangan, dimana selanjutnya akan menjadi suatu informasi yang menggambarkan kinerja koperasi tersebut.

Jadi dengan laporan keuangan dan laporan pendukung lainya yang menjadi bagian integral akan dapat memberikan informasi tentang kondisi keuangan koperasi secara menyeluruh dan seberapa besar tingkat kesehatan koperasi itu sendiri.

\section{Tingkat Kesehatan Koperasi Simpan Pinjam}

Tingkat kesehatan koperasi merupakan suatu tolak ukur untuk kondisi ataupun keadaan koperasi pada suatu periode tertentu.

Koperasi yang berkualitas adalah koperasi yang mampu memberikan pelayanan prima kepada para anggotanya dan mampu menumbuhkan tingkat kepercayaan kepada seluruh anggotanya.

Untuk menciptakan koperasi yang berkualitas, efektif dan efisien, Pemerintah dalam hal ini melalui Kementerian Koperasi Dan Usaha Kecil Dan Menengah terus melakukan sosialisasi terkait dengan telah diterbitkannya Peraturan Deputi Bidang Pengawasan Nomor 06/per/Dep.6/IV/2016 tentang Pedoman Penilaian Kesehatan Koperasi Simpan Pinjam (KSP) dan Unit Simpan Pinjam (USP) Koperasi . Peraturan tersebut menjadi pedoman penting untuk mengukur tingkat kesehatan KSP dan USP Koperasi.

Bagi pemangku kepentingan, mengukur tingkat kesehatan koperasi bukan semata mata untuk menjatuhkan saksi tetapi untuk mengetahui pola pembinaan yang tepat bagi koperasi tersebut. Sebab, koperasi harus mengelola dana dari anggota secara bertanggung jawab dan hati hati.

Sasaran penilaian kesehatan koperasi adalah terwujudnya koperasi yang sehat, menjamin pengelolaan asset, terwujudnya pelayanan yang prima, meningkatkan citra dan kredibilitas koperasi, meningkatnya transparansi dan akuntabilitas, serta meningkatkan manfaat bagi anggota koperasi.

\section{METODOLOGI PENELITIAN}

Penelitian ini merupakan metode penelitian deskriptif dengan pendekatan studi kasus. (Idrus, 2009) Pendekatan studi kasus akan meneliti satu individu atau unit sosial tertentu secara lebih mendalam, dan peneliti biasanya akan berusaha untuk menemukan variabel penting yang terkait dengan subjek yang diteliti.

Sumber data pada penelitian ini adalah data primer dan data sekunder. Data primer berupa wawancara dengan pihak manajemen koperasi simpan pinjam Abdi Sesama dan laporan keuangan koperasi Abdi Sesama. Data Sekunder terutama berupa buku buku referensi dan laporan historis yang telah disusun dan dipublikasikan.

Bahan baku yang akan dikupas oleh penulis berdasakan laporan keuangan koperasi Abdi Sesama per tanggal 31 Desember 2017seperti yang telah diterbitkan dalam rapat anggota tahunan ke-44. Bahan baku tersebut menjadi dasar untuk mengukur tingkat kesehatan koperasi simpan pinjam Abdi Sesama.

Pengukuran kesehatan koperasi mengacu pada pada (Deputi Bidang Pengawasan Kementerian Koperasi Dan Usaha Kecil Dan Menengah Republik Indonesia, 2016).

\section{HASIL DAN PEMBAHASAN}

Ruang lingkup penilaian untuk KSP dan USP Koperasi dilakukan atas 7 aspek yaitu permodalan, kualitas aktiva produktif , manajemen, efisiensi, likuiditas, kemadirian dan pertumbuhan dan jati diri koperasi.

Dalam melakukan penilaian kesehatan KSP dan USP Koperasi , maka terhadap aspek yang dinilai diberikan bobot penilaian sesuai dengan besarnya pengaruh terhadap kesehatan koperasi tersebut. Penilaian aspek dilakukan dalam angka 0 (nol) sampai 100 (seratus)

\section{Permodalan.}

Mengacu pada peraturan pemerintah nomor 06/Per/ Dep.06/IV/2016, aspek permodan memiliki 3 indikator, dengan bobot penilaian maksimal 15,00, dengan perincian sebagai berikut; (a). Rasio modal sendiri terhadap total aset, memiliki bobot 6, (b).

Rasio modal sendiri terhadap pinjaman diberikan yang berisiko, memiliki bobot 6 , dan (c). Rasio kecukupan modal sendiri dengan bobot 3 .

Dari hasil perhitungan skor yang dilakukan, aspek permodalan KSP Abdi Sesama tahun 2017 memperoleh total skor 14.25. Dengan skor tersebut dapat dikatakan aspek permodalan KSP Abdi Sesama memiliki nilai yang sangat sehat dari aspek permodalan. Untuk lebih jelasnya dapat dilihat pada tabel 4 dibawah ini. 
Tabel 4. Aspek Permodalan

\begin{tabular}{lccc}
\hline \multicolumn{1}{c}{ Indikator } & $\mathrm{N}$ & $\mathrm{B}$ & Skor \\
\hline $\begin{array}{l}\text { Rasio modal sendiri terhadap } \\
\text { total asset }\end{array}$ & 100 & 6 & 6,00 \\
\hline $\begin{array}{l}\text { Rasio modal sendiri terhadap } \\
\text { pinjaman diberikan yang } \\
\text { berisiko }\end{array}$ & 100 & 6 & 6,00 \\
\hline Rasio kecukupan modal sendiri & 75 & 3 & 2,25 \\
\hline TOTAL & 15 & 14,25 \\
\hline
\end{tabular}

Keterangan: N=Nilai; $\mathrm{B}=$ Bobot $(\%)$

\section{Aspek Kualitas Aktiva Produktif}

Mengacu pada peraturan pemerintah nomor 06/Per/ Dep.6/IV/2016, aspek kualitas aktiva produktif memiliki 4 indikator, dengan bobot penilaian maksimal 25,00, dengan perincian sebagai berikut;

a. Rasio volume pinjaman pada anggota terhadap volume pinjaman yang diberikan, memiliki bobot 10 ,

b. Rasio pinjaman bermasalah terhadap pinjaman yang diberikan, memiliki bobot 5 ,

c. Rasio cadangan risiko terhadap pinjaman bermasalah, memiliki bobot 5 , dan

d. Rasio pinjaman yang berisiko terhadap pinjaman yang diberikan, memiliki bobot 5. Untuk memperjelas dapat dilihat pada tabel 5 di bawah ini.

Tabel 5. Aspek Kualitas Aktiva Produktif

\begin{tabular}{llll}
\hline \multicolumn{1}{c}{ Indikator } & $\mathrm{N}$ & $\mathrm{B}$ & Skor \\
\hline $\begin{array}{l}\text { Rasiovolume pinjaman pada } \\
\text { anggota terhadap volume } \\
\text { pinjaman yang diberikan }\end{array}$ & 100 & 10 & 10,00 \\
\hline $\begin{array}{l}\text { Rasio risiko pinjaman } \\
\text { bermasalah terhadap pinjaman } \\
\text { yang diberikan }\end{array}$ & 60 & 5 & 3,00 \\
\hline $\begin{array}{l}\text { Rasio cadangan risiko terhadap } \\
\text { pinjaman bermasalah }\end{array}$ & 70 & 5 & 3,50 \\
\hline $\begin{array}{l}\text { Rasio pinjaman yang berisiko } \\
\text { terhadap pinjaman yang } \\
\text { diberikan }\end{array}$ & 100 & 5 & 5,00 \\
\hline TOTAL & $\mathbf{2 5}$ & $\mathbf{2 1 , 5 0}$ \\
\hline
\end{tabular}

Keterangan: N=Nilai; $\mathrm{B}=$ Bobot $(\%)$

Dari tabel 5 tersebut diatas memperlihatkan bahwa aspek kualitas aktiva produktif untuk KSP Abdi Sesama tahun 2017 memperoleh total skor sebesar 21.50. Perolehan skor tersebut belum mencapai skor maksimal tetapi sudah tergolong skor yang tinggi dan sehat.

\section{Aspek Manajemen.}

Penilaian aspek manajemen menurut peraturan pemerintah nomor: 06/Per/Dep.6/IV/2016 meliputi 5 indikator dengan bobot maksimal 15. Perhitungan nilai didasarkan pada hasil penilaian terhadap jawaban atas pertanyaan aspek manajemen terhadap seluruh indikator dengan komposisi pertanyaan sebagai beriku:

a. Manajemen umum memiliki 12 pertanyaan dan untuk setiap jawaban "ya" memperoleh nilai 0,25 . Bobot maksimal 3 .

b. Manajemen kelembagaan memiliki 6 pertanyaan dan untuk setiap jawaban "ya" mendapat nilai 0,50. Bobot maksimal 3.

c. Manajemen permodalan memiliki 5 pertanyaan dan untuk setiap jawaban "ya" mendapat nilai 0,60. Bobot maksimal 3.

d. Manajemen aktiva memiliki 10 pertanyaan dan untuk setiap jawaban "ya" mendapat nilai 0,30 , Bobot maksimal 3.

e. Manajemen likuiditas memiliki 5 pertanyaan dan untuk setiap jawaban "ya" mendapat nilai 0,60 . Bobot maksimal 3.

Dari perhitungan skor yang telah dilakukan untuk aspek manajemen, memperlihatkan bahwa total skor koperasi Abdi Sesama sebesar 14,40. Pencapaian skor tersebut terbilang cukup tinggi dan hampir sempurna. Untuk aspek manajemen tingkat kesehatan koperasi sangat sehat . Untuk lebih jelasnya dapat dilihat pada tabel 6 dibawah ini.

Tabel 6. Aspek Manajemen

\begin{tabular}{llll}
\hline \multicolumn{1}{c}{ Indikator } & J & B & Skor \\
\hline Manajemen umum & 12 & 3 & 3,00 \\
\hline Manjemen kelembagaan & 6 & 3 & 3,00 \\
\hline Manjemen Permodalan & 5 & 3 & 3,00 \\
\hline Manajemen aktiva & 8 & 3 & 2,40 \\
\hline Manjemen likuiditas & 5 & 3 & 3,00 \\
\hline TOTAL & & $\mathbf{1 5}$ & $\mathbf{1 4 , 4 0}$ \\
\hline Ketan
\end{tabular}

Keterangan: J=Jawaban "Ya", B=Bobot

\section{Aspek Efisiensi}

Pengukuran untuk aspek efisiensi menurut peraturan pemerintah nomor: 06/Per/Dep.6/IV/2016 didasarkan pada 3 indikator dengan total bobot maksimal 10, yaitu

a. Rasio biaya operasi pelayanan terhadap partisipasi bruto, memiliki bobot 4 ,

b. Rasio beban usaha terhadapSHU kotor, memiliki bobot 4 dan

c. Rasio efisiensi pelayanan, memilik bobot 2 .

Aspek efisiensi menggambarkan seberapa besar KSP atau USP koperasi mampu memberikan pelayanan yang efisien kepada anggotanya dari penggunaan aset yang dimilikinya. 
Dari perhitungan skor yang telah dilakukan pada aspek efisiensi koperasi KSP Abdi Sesama tahun 2017 menghasilkan skor 9,00.

Berdasarkan hasil skor yang telah didapat tersebut menunjukkan skor yang tinggi walupun belum mencapai skor maksimal sebesar 10,00. Untuk lebih jelasnya dapat dilihat pada tabel 7 .

Tabel 7. Aspek Efisiensi

\begin{tabular}{llll}
\hline \multicolumn{1}{c}{ Indikator } & $\mathrm{N}$ & $\mathrm{B}$ & Skor \\
\hline $\begin{array}{l}\text { Rasio beban operasi anggota } \\
\text { terhadap partisipasi bruto }\end{array}$ & 100 & 4 & 4,00 \\
\hline $\begin{array}{l}\text { Rasio beban usaha terhadap } \\
\text { SHU kotor }\end{array}$ & 75 & 4 & 3,00 \\
\hline Rasio efisiensi pelayanan & 100 & 2 & 2,00 \\
\hline TOTAL & & $\mathbf{1 0}$ & $\mathbf{9 , 0 0}$ \\
\hline
\end{tabular}

Keterangan: N=Nilai; $\mathrm{B}=$ Bobot $(\%)$

\section{Aspek Likuiditas}

Mengacu pada peraturan pemerintah nomor: 06/Per/Dep.6/IV/2016, pengukuran untuk aspek likuiditas menggunakan 2 indikator dengan total maksimal bobot 15. Dua indikator tersebut adalah

a. Rasio kas dan bank terhadap kewajiban lancar, memiliki bobot 10 , dan

b. Rasio pinjaman yang diberikan terhadap dana yang diterima, memiliki bobot 5 .

Berdasarkan hasil perhitungan skor yang telah dilakukan menunjukkan aspek likuiditas KSP Abdi Sesama sebesar 8,75 atau baru tercapai sebesar 58\% dari bobot maksimal. Untuk lebih jelasnya dapat dilihat pada tabel dibawah ini

Tabel 8. Aspek Likuiditas

\begin{tabular}{|l|l|l|l|}
\hline \multicolumn{1}{|c|}{ Indikator } & $\mathrm{N}$ & $\mathrm{B}$ & Skor \\
\hline $\begin{array}{l}\text { Rasio kas dan bank terhadap } \\
\text { kewajiban lancar }\end{array}$ & 50 & 10 & 5,00 \\
\hline $\begin{array}{l}\text { Rasio pinjaman yang diberikan } \\
\text { terhadap dana yang diterima }\end{array}$ & 75 & 5 & 3,75 \\
\hline TOTAL & & $\mathbf{1 5}$ & $\mathbf{8 , 7 5}$ \\
\hline
\end{tabular}

Keterangan: N=Nilai; $\mathrm{B}=\mathrm{Bobot}(\%)$

\section{Aspek Kemandirian dan Pertumbuhan}

Berdasarkan peraturan pemerintah yang telah ditetapkan terkait penilaian kesehatan KSP dan USP koperasi denga nomor : 06/Per/Dep.6/IV/2016, jumlah bobot maksimal untuk aspek kemandirian dan pertumbuhan adalah sebesar 10 .

Penilaian tersebut didasarkan pada 3 indikator sebagai berikut;

a. Rasio rentabilitas asset dengan bobot sebesar 3,

b. Rasio rentabilitas modal sendiri dengan bobot sebesar 3 dan

c. Rasio operaional pelayanan dengan bobot sebesar 4.
Berdasarkan hasil perhitungan skor yang telah dilakukan, jumlah skor untuk aspek kemandirian dan pertumbuhan KSP Abdi Sesama tahun 2017 adalah sebesar 5.50. Secara prosentase dari bobot maksimal baru mencapai $55 \%$, sehingga dapat dikatakan skor tersebut cukup rendah jika mengacu pada bobot maksimal yang disyaratkan sebesar 10 .

Tabel 9. Aspek Kemandirian dan Pertumbuhan

\begin{tabular}{llll}
\hline \multicolumn{1}{c}{ Indikator } & N & B & Skor \\
\hline Rasio rentabilitas aset & 25 & 3 & 0,75 \\
\hline $\begin{array}{l}\text { Rasio rentabilitas modal } \\
\text { sendiri }\end{array}$ & 25 & 3 & 0,75 \\
\hline $\begin{array}{l}\text { Rasio kemandirian } \\
\text { operasional pelayanan }\end{array}$ & 100 & 4 & 4,00 \\
\hline TOTAL & & 10 & 5,50 \\
\hline
\end{tabular}

Keterangan: N=Nilai; B=Bobot $(\%)$

\section{Aspek Jatidiri Koperasi.}

Pengukuran aspek jatidiri koperasi dimaksudkan untuk mengukur keberhasilan koperasi ddalam mencapai tujuan koperasi itu sendiri. Mengacu pada peraturan pemerintah nomor: 06/Per/Dep.6/IV/2016, pengukuran tersebut didasarkan pada 2 indikator yang secara total memiliki bobot maksimal sebesar 10. Dua indikator tersebut adalah sebagai berikut:

a. Rasio Partisipasi Bruto. Rasio ini untuk mengukur tingkat kemampuan koperasi dalam melayani anggota. Semakin tinggi prosentase yang dihasilkan maka semakin baik. Partisipasi bruto adalah kontribusi anggota kepada koperasi sebagai imbalan penyerahan jasa kepada anggota, yang mencakup beban pokok dan partisipasi netto. Rasio partisipasi bruto memiliki bobot sebesar 7 .

b. Rasio Promosi Ekonomi Anggota. Rasio ini untuk mengukur kemampuan koperasi memberikan manfaat efisien partisipasi dan manfaat efisiensi biaya koperasi dengan simpanan pokok dan simpanan wajib. Hasil yang didapat, semakin tinggi prosentasenya semakin baik. Rasio promosi ekonomi anggota memiliki bobot sebesar 3 .

Tabel 10. Aspek Jatidiri Koperasi

\begin{tabular}{|l|l|l|l|}
\hline \multicolumn{1}{|c|}{ Indikator } & $\mathrm{N}$ & $\mathrm{B}$ & Skor \\
\hline Rasio partisipasi bruto & 75 & 7 & 5,25 \\
\hline $\begin{array}{l}\text { Rasio promosi ekonomi } \\
\text { anggota }\end{array}$ & 100 & 3 & 3,00 \\
\hline TOTAL & & 10 & 8,25 \\
\hline
\end{tabular}

Keterangan: N=Nilai; B=Bobot $(\%)$

Dari tabel 10 tersebut diatas terlihat bahwa skor untuk aspek jatidiri koperasi KSP Abdi Sesama 
tahun 2017 sebesar 8,25. Jumlah skor tersebut cukup baik jika dibandingkan dengan bobot maksimal yang disyaratkan sebesar 10 .

\section{KESIMPULAN}

Pengukuran atau penilaian kesehatan KSP Abdi Sesama yang telah dilakukan dengan mengacu pada peraturan (Deputi Bidang Pengawasan Kementerian Koperasi Dan Usaha Kecil Dan Menengah Republik Indonesia, 2016) terhadap 7 aspek.

Tabel 11. Hasil Skor Kesehatan

KSP Abdi Sesama Tahun 2017

\begin{tabular}{clc}
\hline No. & \multicolumn{1}{c}{ Aspek Pengukuran } & B \\
\hline 1 & Aspek Permodalan & 15 \\
\hline 2 & $\begin{array}{l}\text { Aspek Kualitas Aktiva } \\
\text { Produktif }\end{array}$ & 25 \\
\hline 3 & Aspek Manajemen & 15 \\
\hline 4 & Aspek Efisiensi & 10 \\
\hline 5 & Aspek Likuiditas & 15 \\
\hline 6 & $\begin{array}{l}\text { Aspek Kemandirian dan } \\
\text { Pertumbuhan }\end{array}$ & 10 \\
\hline 7 & Aspek Jatidiri Koperasi & 10 \\
\hline & TOTAL & 100 \\
\hline
\end{tabular}

Keterangan; $\mathrm{B}=$ Bobot $(\%)$

Mengacu pada hasil tersebut diatas maka KSP Abdi Sesama untuk tahun 2017 dengan perolehan total skor 81,65 masuk kategori sehat. Menurut peraturan pemerintah nomor: 06/Per/Dep.6/IV/2016, kategori sehat jika hasil penilaian diperoleh total skor $80,00 \leq \mathrm{X} \leq 100$.

Namun begitu ada beberapa aspek yang harus menjadi perhatian serius, karena memiliki skor yang rendah, yaitu aspek likuiditas dan aspek kemadirian dan pertumbuhan.

Dua asperk tersebut menjadi kelemahan yang harus diperbaikan untuk tahun tahun kedepan. Untuk aspek dengan perolehan skor yang baik hendaknya terus ditingkatkan agar tingkat kepercayaan anggota terhadap koperasi menjadi sangat tinggi.

Terhadap anggota yang mengalami kesulitan keuangan yang pada akhirnya berimbas pada macetnya angsuran hendaknya pengurus koperasi secara aktif melakukan pendampingan positip agar dapat dicarikan solusi terbaik.

Hal ini tentunya akan berdampak positip terhadap 7 aspek penilaian, yaitu pinjaman beresiko atau pinjaman bermasalah menjadi relatif kecil, dana yang diterima dari anggota akan bertambah.

Dengan pertambahnya dana atau lancarnya anggota membayar angsuran pokok plus bunga akan meningkatkan nilai kas koperasi. Kas bertambah maka kemampuan koperasi dalam meyalurkan pinjaman juga akan menjadi kuat yang pada akhirnya kopersi akan mampu menciptakan SHU yang lebih besar lagi.

\section{REFERENSI}

Baswir, R. (2000). No Title (Pertama). Yogyakarta: BPFE.

Deputi Bidang Pengawasan Kementerian Koperasi Dan Usaha Kecil Dan Menengah Republik Indonesia. (2016). Pedoman Penilaian Kesehatan Koperasi Simpan Pinjam Dan Unit Simpan Pinjam Koperasi Nomor: 06/Per/Dep.6/IV/2016. Jakarta.

Fahmi, I. (2011). Analisis Kinerja Keuangan. Bandung: Alfabeta.

Goenawan, H., \& Natalia, D. (2016). Analisis Tingkat Kesehatan Koperasi Pada Koperasi Simpan Pinjam Di Kabupaten Tulang Bawang Barat. Jurnal Akuntansi \& Keuangan, 7(2), 169-191.

Harapan, S. S. (2009). Analisis Kritis Dan Laporan Keuangan. Jakarta: Raja Grafindo Persada.

Idrus, M. (2009). Metode Penelitian Ilmu Sosial Pendekatan Kualitatif Dan Kuantitatif. Jakarta: Erlangga.

Jumingan. (2011). Analisa Laporan Keuangan. Jakarta: Bumi Aksara.

Kasmir. (2010). Analisis Laporan Keuangan (Ketiga). Jakarta: Rajawali Pers.

Margaretha, F. (2011). Manajemen Keuangan Untuk Non Keuangan. Jakarta: Erlangga.

Rudiwantoro, A. (2019). Mengukur Tingkat Kesehatan Koperasi Simpan Pinjam Berdasarkan Peraturan No: 06/PER/DEP.6/IV/2016 (Studi Kasus Pada Koperasi Abdi Sesama - Palembang). Moneter, 6(1), 45-52.

Subandi. (2009). Ekonomi Koperasi (Teori Dan Praktek). Bandung: Alfabeta.

Sumarsono, S. (2003). Manajemen Koperasi. Yogyakarta: Graha Ilmu.

Undang-Undang Republik Indonesia Nomor 25 Tahun 1992. (1992). Perkoperasian. Jakarta. 
Mengukur Tingkat Kesehatan Koperasi Simpan Pinjam Berdasarkan Peraturan Nomor: 06/PER/DEP.6/IV/2016 (Studi Kasus Pada Koperasi Abdi Sesama - Palembang)

\section{PROFIL PENULIS}

Andreas Rudiwantoro, SE., MM. Menyelesaikan pendidikan S1 Ekonomi di Sekolah Tinggi Ilmu Ekonomi Perbanas Jakarta tahun 1996. Lulus Magister Manajemen, Sekolah Tinggi Ilmu Ekonomi IPWIJA tahun 2007. Aktif Mengajar sebagai dosen dari tahun 2010 hingga sekarang di Akademi Komputer Akuntansi BSI . Mengampu mata kuliah akuntansi dasar, akuntansi menengah, akuntansi lanjutan, analisis laporan keuangan dan akuntansi biaya. Selain aktif mengajar, tercatat juga sebagai pegawai tetap di salah satu perusahaan swasta. 